\title{
Identification of a protein kinase activity that phosphorylates connexin43 in a $\mathrm{pH}$-dependent manner
}

\section{P. Yahuaca², J.F. Ek-Vitorin², P. Rush'2, M. Delmar ${ }^{2}$ and S.M. Taffet ${ }^{1}$}

\author{
${ }^{1}$ Department of Microbiology and Immunology and \\ ${ }^{2}$ Department of Pharmacology, SUNY H ealth Science Center at Syracuse, \\ Syracuse, NY, USA
}

\section{Correspondence \\ S.M. Taffet \\ Department of Microbiology and \\ Immunology \\ SUNY Health Science Center at \\ Syracuse \\ 750 E. Adams Street \\ Syracuse, NY 13210 \\ USA \\ Fax: + 1-315-464-4417 \\ E-mail: taffets@hscsyr.edu \\ Presented at the Meeting \\ "Gap Junctions in the Nervous and \\ Cardiovascular Systems: Clinical \\ Implications", Rio de Janeiro, RJ, \\ Brazil, June 6-11, 1998. \\ Research supported by grant PO 1-HL39707 from the National Heart, Lung and Blood Institute and by a grant-in-aid from the American Heart Association, New York Affiliate. The work was performed during M ario Delmar's tenure as an Established Investigator of the American Heart Association. \\ The current address of $P$. Yahuaca is Department of Pharmacology, School of Medicine, Universidad Autónoma de Zacatecas, Carretera a la Bufa No. 5, Zacatecas, Zac. 98000, México.}

Received July 30, 1999 Accepted September 15, 1999

\section{Abstract}

The carboxyl-terminal (CT) domain of connexin43 (Cx43) has been implicated in both hormonal and $\mathrm{pH}$-dependent gating of the gap junction channel. An in vitro assay was utilized to determine whether the acidification of cell extracts results in the activation of a protein kinase that can phosphorylate the CT domain. A glutathione Stransferase (GST)-fusion protein was bound to Sephadex beads and used as a target for protein kinase phosphorylation. A protein extract produced from sheep heart was allowed to bind to the fusion proteincoated beads. The bound proteins were washed and then incubated with ${ }^{32} \mathrm{P}$-ATP. Phosphorylation was assessed after the proteins were resolved by SDS-PAGE. Incubation at $\mathrm{pH} 7.5$ resulted in a minimal amount of phosphorylation while incubation at $\mathrm{pH} 6.5$ resulted in significant phosphorylation reaction. Maximal activity was achieved when both the binding and kinase reactions were performed at $\mathrm{pH}$ 6.5. The protein kinase activity was stronger when the incubations were performed with manganese rather than magnesium. Mutants of Cx43 which lack the serines between amino acids 364-374 could not be phosphorylated in the in vitro kinase reaction, indicating that this is a likely target of this reaction. These results indicate that there is a protein kinase activity in cells that becomes more active at lower $\mathrm{pH}$ and can phosphorylate $\mathrm{Cx} 43$.

\section{Introduction}

Connexin43 (Cx43) is one of a group of integral membrane proteins that form intercellular channels called gap junctions. Six connexin proteins form a hexameric structure called a connexon, which constitutes a hemichannel. Two connexons, each provided by respective neighboring cells, can be aligned and assembled to form an intercellular channel.

\author{
Key words \\ - Connexin \\ - Phosphorylation \\ - Phosphotransferases \\ - Protein kinase
}

All connexins share a common hydropathy profile consisting of four membrane spanning domains, one cytoplasmic loop (CL) and two extracellular loops (EL 1, EL 2); both amino and carboxyl terminals (AT and CT, respectively) seem to be located in the intracellular space. Interestingly, partial truncation of the CT has not prevented functional expression in most connexins tested, including: Cx32 (1), Cx37 (2), Cx40 (2), Cx43 (3), Cx45 (4), and Cx50 $(5,6)$. The latter suggests 
that the $\mathrm{CT}$ is not an essential component of the channel pore. It has been demonstrated that the CT domain of $\mathrm{Cx} 43$ plays an important role in regulation of intercellular communication. Changes in Cx43-mediated gap junctional communication by such factors as acidification, growth factors, oncogenes and activators of protein kinases have been shown to require an intact $\mathrm{CT}$ domain.

Cx43 is commonly found as a phosphoprotein. A number of potential consensus sites for both serine/threonine and tyrosine kinases can be identified. Detailed biochemical studies have shown that $\mathrm{Cx} 43$ acts as a substrate for phosphorylation by $\mathrm{v}-\mathrm{Src}(7,8)$, protein kinase $\mathrm{C}$ (PKC) and mitogen-activated protein kinase (MAPK) (9-11). Recent evidence also suggests that $\mathrm{Cx} 43$ was phosphorylated by the mitosis-associated cdc-2 kinase (12) and cGMP-dependent phosphorylation of rat $\mathrm{Cx} 43$ has also been demonstrated (13). The functional consequence of $\mathrm{Cx} 43$ phosphorylation is rather complex. For example, activation of PKC leads to a shift in the unitary conductance of the channel toward lower conductance states (14). However, there is a seemingly paradoxical increase in macroscopic conductance, probably due to an increase in open probability $(15,16)$. These results show that electrical and metabolic coupling are not necessarily directly related, and can be regulated differently. Phosphorylation of Cx43 by MAPK also leads to a decrease in coupling $(17,18)$. With respect to tyrosine kinases, co-expression of v-Src leads to phosphorylation of $\mathrm{Cx} 43$ and prevents the formation of junctional conductance in $\mathrm{Cx} 43$-expressing oocytes and this regulation has been shown to be dependent on the CT domain (19). Finally, it is interesting to note that the Srchomology 3 (SH3) domain of v-Src binds to the carboxyl terminal domain of $\mathrm{Cx} 43$ (7). The latter opens the possibility that the CT of Cx43 may associate with SH3-containing proteins thus modifying the degree of communication between cells.
Our long-term goal is to understand the mechanisms responsible for chemical regulation of gap junctions. We have focused on the molecular steps involved in the closure of $\mathrm{Cx} 43$ by low intracellular $\mathrm{pH}$ (pHi). Several protein kinases are activated under conditions of lower intracellular $\mathrm{pH}$ including MAPK (20), pp60 Src (21) and stress-activated protein kinases (SAPK) (22). Interestingly, both Src and MAPK are known to phosphorylate $\mathrm{Cx} 43$ in the $\mathrm{CT}$ domain. Due to the requirement for the $\mathrm{CT}$ domain for regulation by both lower $\mathrm{pHi}$ and protein kinases, we sought to determine whether we could detect a protein kinase activity that would result in the phosphorylation of $\mathrm{Cx} 43$ under low $\mathrm{pH}$-dependent conditions. To do this we have generated a fusion protein consisting of glutathione-S-transferase (GST) with the CT domain of $\mathrm{Cx} 43$. We refer to this 40-kDa fusion protein as GST-Cx43-CT. We used an in vitro assay to determine whether lower $\mathrm{pH}$ could increase the binding to or phosphorylation of $\mathrm{Cx} 43-\mathrm{CT}$ by a protein kinase present in a cell or tissue extract. We were able to demonstrate that a protein kinase activity did exist that phosphorylated $\mathrm{Cx} 43-\mathrm{CT}$ on a serine residue and that this phosphorylation was greatly enhanced if the reaction occurred at low $\mathrm{pH}(6.5)$.

\section{Experimental procedures}

\section{Production of Cx43 fusion proteins}

The cytoplasmic tail domain of connexin 43 (Cx43-CT) was cloned, using the polymerase chain reaction, into the bacterial expression vector, pGEX-2T (Phamacia, Uppsala, Sweden). This vector produces fusion proteins of $\mathrm{Cx} 43-\mathrm{CT}$ covalently bound to GST. The template for the cloning of Cx43 was rat connexin 43 provided by Dr. David Paul (Harvard University). Mutant connexin 43 templates were produced as previously described (23). Deletion mutants are identified by the numbers of the deleted 
amino acids. We studied the phosphorylation of the following Cx43 mutants; 261280, 281-300 and 364-373.

To clone the wild type or mutant CT domains the following primers were used: forward GAA GGA TCC ATG AGC GAT CCT TAC CAC GCC and reverse - GCT TGA ATT CCA AGC CGG TTT AAA TCT CC. PCR was performed with $p f u$ polymerase (Stratagene, La Jolla, CA, USA). After ligation into pGEX-2T, the plasmids were grown in $E$. coli $\mathrm{DH} 5 \alpha$. The fusion protein was expressed by incubating the bacteria in LB broth with $0.5 \mathrm{mM}$ IPTG for 3-5 $\mathrm{h}$. The bacteria were washed in Tris-buffered saline (TBS) and resuspended in TBS (1/10 of the volume of the LB broth culture) with $1 \mathrm{mM}$ DTT. The cells were then sonicated on ice for $1 \mathrm{~min}$. After sonication, NP-40 and PMSF were added to final concentrations of $1 \%$ and $1 \mathrm{mM}$, respectively. The extract was then cleared by centrifugation for $20 \mathrm{~min}$ at $17,000 \mathrm{~g}$ and the extracts were stored at $-70^{\circ} \mathrm{C}$. The presence of the fusion protein was confirmed by polyacrylamide gel electrophoresis (SDS-PAGE). To prepare fusion protein-coated beads, $1 \mathrm{ml}$ of bacterial lysate was bound to $50 \mu 1$ of glutathione-Sepharose $4 \mathrm{~B}$ beads (Pharmacia) at $4^{\circ} \mathrm{C}$ for $2.5 \mathrm{~h}$ while gently rocking. After loading, the beads were washed with TBS. The beads were then incubated with $2 \mathrm{mM}$ ATP and $10 \mathrm{mM} \mathrm{MgCl}$ for $20 \mathrm{~min}$ at $37^{\circ} \mathrm{C}$ in order to remove a high molecular weight contaminant from the beads. The beads were then washed three times with TBS and stored for up to one week in $1 \mathrm{ml}$ of TBS with $1 \% \mathrm{NP}-40$ and 1 mM DTT.

\section{Heart extract preparation and in vitro kinase assay}

Sheep heart extracts were prepared by homogenizing $1 \mathrm{~g}$ of tissue (ventricle) in 10 $\mathrm{ml}$ of lysis buffer (50 mM MOPS (3-[Nmorpholino] propanesulfonic acid, $\mathrm{pH}$ 7.5), $50 \mathrm{mM} \mathrm{NaCl}, 1 \mathrm{mM}$ EGTA, $2 \mathrm{mM} \mathrm{MgCl}$,
0.1\% B-mercaptoethanol, 1\% Triton X-100, and complete protease inhibitor cocktail (Boehringer Mannheim, Mannheim, Germany). The extracts were cleared by centrifugation (14,500 rpm, $20 \mathrm{~min}$ ), assessed for protein content by the method of Bradford, and stored at $-70^{\circ} \mathrm{C}$ until use.

The in vitro kinase assay was derived from the assay system described by Turner et al. $(24,25)$. For analysis of in vitro protein kinase activity, the fusion protein-coated beads were washed once and resuspended in $500 \mu 1$ of lysis buffer. For each individual tube of the kinase assay, $30 \mu 1$ of these beads were placed in $1 \mathrm{ml}$ of lysis buffer (adjusted to the appropriate $\mathrm{pH}$ ) with $1 \mathrm{mg}$ (protein content) of sheep heart extract. Binding of the extract to the beads was at $4^{\circ} \mathrm{C}$ for 90 min with gentle rocking. Following binding, the beads were then washed three times with lysis buffer and then washed two times in kinase buffer (50 mM MOPS, $3 \mathrm{mM} \mathrm{MnCl}$, again at the appropriate $\mathrm{pH}$ ).

The pellet was resuspended in $20 \mu 1$ of kinase buffer and $5 \mu \mathrm{Ci}$ of $\left[\gamma^{32} \mathrm{P}\right]$ ATP $(4500$ $\mathrm{Ci} / \mathrm{mmol}$, ICN Biomedicals, Inc., Costa Mesa, CA, USA). Unless otherwise noted, the kinase reaction was for $20 \mathrm{~min}$ at $20^{\circ} \mathrm{C}$. The reaction was terminated by the addition of 6X SDS sample buffer and the sample was placed in boiling water for $5 \mathrm{~min}$. Samples were then resolved by SDS-PAGE, using an $11 \%$ resolving gel. Following SDS-PAGE, the proteins were visualized by staining with Coomassie blue (GelCode ${ }^{\circledR}$, Pierce Chemical Co., Millford, IL, USA). Gels were dried, and analyzed by PhosphoImager (Molecular Dynamics, Sunnyvale, CA, USA).

\section{Results}

We utilized an in vitro kinase assay to determine whether cells had an activity that could result in the phosphorylation of connexin43. This assay utilized a construct of Cx43-CT fused to GST. Tissue extracts derived from sheep heart were prepared and 
Figure 1 - Phosphorylation of $\mathrm{Cx} 43$. An in vitro kinase reaction was performed using a Cx43-CTGST fusion protein. The fusion protein was immobilized on glutathione Sephadex resin and incubated with $1 \mathrm{mg}$ of sheep heart extract for 90 min. Binding reactions were performed in MOPS buffer at either $\mathrm{pH} 6.5$ or 7.5. After washing, the beads were incubated with $5 \mu \mathrm{Ci}$ of $\left[\gamma^{-32} \mathrm{P}\right]$ ATP in $50 \mathrm{mM}$ MOPS and $3 \mathrm{mM} \mathrm{MnCl} 2$ at the $\mathrm{pH}$ indicated. The reaction was stopped by the addition of SDS sample buffer and the proteins were resolved by SDSPAGE. Visualization was performed using a Phospholmager. The image shown was representative of at least three experiments. The migration of the $\mathrm{Cx} 43-$ CT-GST fusion protein is marked. Phosphorylation is enhanced when the binding and/or kinase incubations are at pH 6.5. CT-GST, Carboxy terminal-glutathione-Stransferase fusion protein. allowed to interact with the GST-CT fusion protein bound to a Sepharose bead. After binding, the beads were washed to remove unbound proteins and incubated with $\left[\gamma^{32} \mathrm{P}\right]$ ATP. The proteins were resolved by SDSPAGE and phosphorylation was assessed by PhosphoImager analysis. Figure 1 represents an example of one such experiment. When both the binding and kinase steps of this assay were performed at $\mathrm{pH} 7.5$ there was minimal phosphorylation of the GST-CT fusion protein. Under these conditions, there was also minimal phosphorylation of a second protein of approximately $60 \mathrm{kDa}$. In previous studies, we have determined that an intracellular $\mathrm{pH}$ of 6.5 was sufficient to cause the closure of $\mathrm{Cx} 43$ channels expressed in Xenopus oocytes. When both the binding and kinase steps were performed at $\mathrm{pH} 6.5$ there was a dramatic increase in the phosphorylation of GST-Cx43-CT and a significant increase in phosphorylation of the 60$\mathrm{kDa}$ protein. No detectable phosphorylation of a control GST protein was observed (data not shown). When only the kinase or binding step was performed at $\mathrm{pH} 6.5$ the result was an intermediate level of phosphorylation. This indicates that the kinase was both better

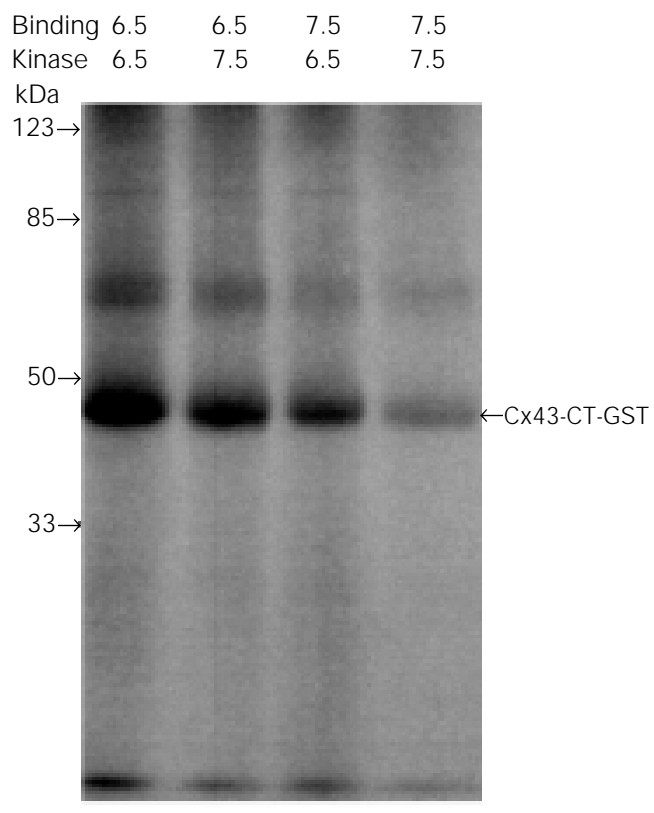

retained in the bead-GST-CX43-CT complex at lower $\mathrm{pH}$ and was more active at lower $\mathrm{pH}$.

In order to determine whether this might be a general activation of protein kinases, we produced a second GST fusion protein construct with Cx46-CT. This protein was produced and used in a manner identical to Cx43. Both Cx43-CT and Cx46-CT, GST protein constructs, were used as targets for binding and phosphorylation by sheep heart extracts. Figure 2 shows the phosphorylation of Cx43-CT-GST fusion proteins at $\mathrm{pH}$ 6.5 and $\mathrm{pH} 7.5$ (for both the binding and kinase steps). As expected, there was an increase in phosphorylation of $\mathrm{Cx} 43-\mathrm{CT}$. When Cx46-CT was used in place of $\mathrm{Cx} 43$ there was no detectable phosphorylation at $\mathrm{pH} 7.5$ and only a small, although detectable, phosphorylation at $\mathrm{pH}$ 6.5. The amount of connexin-GST fusion protein was shown to be similar based on the intensity of Coomassie staining. This phosphorylation reaction was, therefore, not a general increase in protein kinase activity but had some specificity. Testing of CT constructs derived from other connexin proteins would be required to determine the range of possible substrates of this protein kinase.

In order to better define the role of $\mathrm{pH}$ in the binding and kinase assays, the $\mathrm{pH}$ of one of these steps was held constant while the $\mathrm{pH}$ of the other was varied. In panel A of Figure 3 the kinase assay was held at either $\mathrm{pH} 6.5$ (open bars) or $\mathrm{pH} 7.5$ (closed bars), while the $\mathrm{pH}$ of the binding reaction was changed. The results were quantified and then normalized so that the highest value was $100 \%$. As expected, the curve obtained when the kinase assay was performed at lower $\mathrm{pH}$ was significantly higher. This curve indicates that the lower the $\mathrm{pH}$, the more kinase can bind to the GST-Cx43-CT. Due to the very low level of activity in this experiment, it is not possible to make a definitive comment about the kinase activity obtained when the kinase reaction was performed at $\mathrm{pH}$ 7.5. In panel $\mathrm{B}$ 
of Figure 3, the $\mathrm{pH}$ of the binding step was held constant at either $\mathrm{pH} 6.5$ (open bars) or pH 7.5 (closed bars). The pH of the kinase assay was then altered as indicated in the chart. The activity was higher when the binding was performed at the lower $\mathrm{pH}$ as is expected from the results shown in panel A. At both pHs of binding, the activity was higher when the kinase reaction was performed at a lower $\mathrm{pH}$, reaching a maximum at $\mathrm{pH}$ 6.5. However, unlike the binding step, this activity did not seem to continue to increase as the $\mathrm{pH}$ was reduced.

In our initial studies, the kinase assays were performed in a buffer that utilized manganese as the source of divalent cations. In order to further characterize the kinase activity the experiments were performed with either $3 \mathrm{mM} \mathrm{MgCl}_{2}$ or $3 \mathrm{mM} \mathrm{MnCl}_{2}$. Figure 4 demonstrates that the activation of the protein kinase for phosphorylation of both the GST-Cx43-CT protein and the other phosphorylation targets in the extract was greatly enhanced by the presence of manganese rather than magnesium.

To further analyze the phosphorylation reaction, mutants of $\mathrm{Cx} 43-\mathrm{CT}$ were cloned into the GST expression vector. These proteins were expressed and analyzed for reaction with the acidification-activated protein kinase activity as before. The results of one such experiment are presented in Figure 5. When wild type $\mathrm{Cx} 43-\mathrm{CT}$ was used there was a significant increase in phosphorylation seen when the $\mathrm{pH}$ was dropped from 7.5 to 6.5. Conversely, no phosphorylation was observed when GST alone was used as a potential phosphate acceptor. Mutants of Cx43-CT were chosen based on the presence of potential phosphorylation sites. A deletion of the protein from amino acid 261 to 280 was phosphorylated in an acidification dependent manner although the overall level of phosphorylation was slightly less intense than that observed for the wild type protein. Similarly, there was phosphorylation of a mutant peptide that lacked amino acids 281 to 300 . There was, however, a dramatic loss of demonstrable kinase activity when a deletion of amino acids 364-373 was tested. This deletion removes six serines that make up consensus sites for several protein kinases. From these results, the site
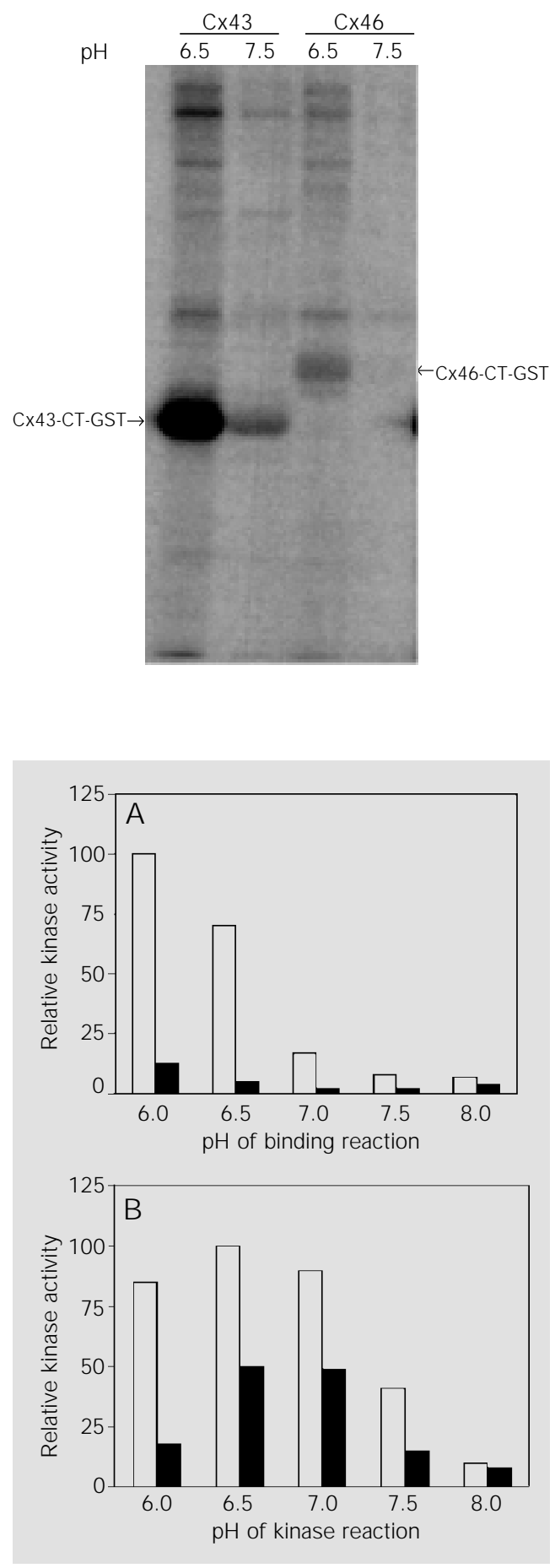

Figure 2 - Comparison of in vitro phosphorylation of $\mathrm{Cx} 43$ and Cx46. GST (glutathione-S-transferase) fusion proteins derived from $\mathrm{C} \times 43$ or $\mathrm{C} \times 46$ were prepared and analyzed for phosphorylation by sheep heart extracts. The $\mathrm{pH}$ of both the binding and kinase reactions was the same and is indicated in the figure. The results indicate that the $\mathrm{ki}-$ nase reaction was enhanced against $\mathrm{Cx} 43$ at lower $\mathrm{pH}$.

Figure 3 - Titration of $\mathrm{pH}$ in the in vitro kinase assay. In this assay, the $\mathrm{pH}$ of either the binding or kinase reaction was held constant while the $\mathrm{pH}$ of the other reaction was varied. The phosphorylation of the Cx43-CT-GST fusion protein was quantified by Phospholmager analysis. Two lanes for each $\mathrm{pH}$ were quantified and the results were averaged. The figure is representative of three experiments. Panel $\mathrm{A}$, The $\mathrm{pH}$ of the kinase reaction was held at either pH 6.5 (open bars) or pH 7.5 (closed bars) while the $\mathrm{pH}$ of the binding reaction was varied from 6 to 8 at $0.5-\mathrm{pH}$ unit intervals. Panel B, The $\mathrm{pH}$ of the binding reaction was held at either $\mathrm{pH} 6.5$ (open bars) or pH 7.5 (closed bars) while the $\mathrm{pH}$ of the kinase reaction was varied from 6 to 8 at $0.5-\mathrm{pH}$ unit intervals. 
of phosphorylation appears to be primarily in the serines at the $\mathrm{C}$-terminal end of the molecule.

\section{Discussion}

In this report, we demonstrate that tissue extracts contain a protein kinase or kinases that can specifically interact with the carboxyl terminal domain of $\mathrm{Cx} 43$ and phosphorylate the protein. The unique property of these kinases is that the interaction with, and the phosphorylation of, connexin are enhanced by reducing the $\mathrm{pH}$ to 6.5 . This coincides with the intracellular $\mathrm{pH}$ required to gate $\mathrm{Cx} 43$. The assay system chosen requires that the interaction of the protein kinase with the target protein be able to with-

Figure 4 - The $\mathrm{pH}$-dependent kinase is more active in the presence of $\mathrm{Mn}$ than $\mathrm{Mg}$. The in vitro kinase assay was performed at $\mathrm{pH} 6.5$ and 7.5 (the $\mathrm{pH}$ of the binding and kinase steps was constant). The divalent cation present in the kinase reaction was either $3 \mathrm{mM} \mathrm{MgCl} 2$ or 3 $\mathrm{mM} \mathrm{MnCl} 2$ as indicated. Kinase activity was significantly enhanced by the presence of manganese. CT-GST, Carboxyl terminal-glutathione-S-transferase fusion protein.

Figure 5 - Analysis of phosphorylation of Cx43 mutants. GST (glutathione-S-transferase) fusion proteins were prepared that had deletions in the CT (carboxyl terminal) domain of Cx43. The mutants tested had deletions from amino acids 261-280, 281-300 and 364-373. In addition, both wild type Cx43-CT and GST alone were tested. The mutants were tested with the reactions performed at both $\mathrm{pH} 6.5$ and $\mathrm{pH}$

7.5. The presence of equal amounts of fusion protein in the reaction was confirmed by the Coomassie blue staining of the gel. The migration of the Cx43-CT-GST fusion protein is marked. The mutated isoforms migrate slightly faster. The phosphorylation of the fusion protein was greatly reduced by the removal of the region from amino acids 364 and 373. stand multiple washing steps. Therefore, we can conclude that a relatively strong binding interaction must take place between the kinase and $\mathrm{Cx} 43$. The phosphorylation was somewhat specific. There was no detectable phosphorylation of the GST carrier protein and only weak phosphorylation of the Cx46CT domain used as a control.

Many studies have shown that phosphorylation is a common modification of the connexin molecule (26, see also 27$)$. Others have demonstrated that phosphorylation of Cx43 results in an alteration of the unitary conductance of connexin channels $(14,28$ $30)$. The activation of kinases coincides with a shift of the unitary conductance of gap junction channels from neonatal cardiac myocytes (31). While under dephosphorylating conditions, human $\mathrm{Cx} 43$ channels show a predominance of larger unitary conductance (28). Furthermore, it has been suggested that permeability and single channel conductance of $\mathrm{Cx} 43$ gap junction channels are independently regulated, and that electrical and metabolic coupling are differentially modulated by various phosphorylating conditions (15). Taken together, these data suggest a relationship between phosphorylation of connexins and modification of intercellular communication.

We have previously demonstrated that the $\mathrm{CT}$ domain of $\mathrm{Cx} 43$ is required for acidification-induced gating $(32,33)$. This domain is also required for other gating reactions $(19,34)$. A number of protein kinases are known to phosphorylate $\mathrm{Cx} 43$ and modify the gating of the channels. In many cases, the phosphorylation reactions have been shown to occur in the $\mathrm{CT}$ domain. Truncation or mutation of the $\mathrm{CT}$ domain of $\mathrm{Cx} 43$ results in a loss of the ability of $\mathrm{Cx} 43$ to be modulated by a number of protein kinases or factors known to activate protein kinases. In one example, Src kinase was unable to induce the gating of a truncated form of $\mathrm{Cx} 43$ (19) unless the CT domain was also expressed in the cell. In another example, mu- 
tation of three serines that represent potential MAPK phosphorylation sites reduces the ability of growth factors to gate connexins (17). It is possible that the acidificationinduced phosphorylation of connexin described in this manuscript may act as a mediator in acidification-induced gating.

It has been suggested that many regulators of cell-to-cell coupling act in concert. For example, $\mathrm{pHi}$ and $\mathrm{Ca}$ have been reported to act together to regulate channel activity (35-37). More recent studies have proposed that acidification-induced gating does not directly affect cell coupling, but may act through the ubiquitous calcium-receptor protein, calmodulin (38). It has also been suggested that calcium-induced gating of gap junction channels could result from the activation of specific kinases, with consequent connexin phosphorylation (39). It is interesting to note that there are multiple calcium/ calmodulin-dependent kinase II (CAMK II) phosphorylation sites in the carboxyl-terminal domain of $\mathrm{Cx} 43$.

Our studies localized the region of phosphorylation to a serine-rich region at the Cterminal end of the $\mathrm{Cx} 43$ molecule. This region contains consensus phosphorylation sites for PKC, cAMP-dependent protein kinase and CAMK. To date, our studies have not been able to specifically detect any of these kinases in the proteins bound to $\mathrm{Cx} 43$ $\mathrm{CT}$ at lower $\mathrm{pH}$. We have also not been able to block the acidification-induced phosphorylation reactions using inhibitors of these kinases. Future studies will be performed to identify the kinase or kinases involved.

\section{Acknowledgments}

We thank Wanda Coombs and Marta Mastroianni for their excellent technical support.

\section{References}

1. Wemer R, Levine E, Rabadan-Diehl C \& Dahl G (1991). Gating properties of connexin32 cell-cell channels and their mutants expressed in Xenopus oocytes. Proceedings of the Royal Society of London, 243: 5-11.

2. Stergiopoulos K, Alvarado J L, Ek-Vitorin J F, Taffet SM \& Delmar M (1999). Heterodomain interactions as a mechanism for the regulation of connexin channels. Circulation Research, 84: 1144-1155.

3. Dunham B, Liu S, Taffet SM, Trabka-J anik E, Delmar M, Petryshyn R, Zheng S, Perzova R \& Vallano ML (1992). Immunolocalization and expression of functional and nonfunctional cell-to-cell channels from wild-type and mutant rat heart connexin43 cDNA. Circulation Research, 70: 1233-1243.

4. Koval M, Geist ST, Westphale EM, Kemendy $A E$, Civitelli R, Beyer EC \& Steinberg TH (1995). Transfected connexin45 alters gap junction permeability in cells expressing endogenous connexin43. J ournal of Cell Biology, 130: 987995.

5. Lin J S, Eckert R, Kistler J \& Donaldson P (1998). Spatial differences in gap junction gating in the lens are a consequence of connexin cleavage. European J ournal of Cell Biology, 76: 246-250.

6. Lin J S, Fitzgerald S, Dong $Y$, Knight $C$, Donaldson P \& Kistler J (1997). Processing of the gap junction protein connexin50 in the ocular lens is accomplished by calpain. European J ournal of Cell Biology, 73: 141-149.

7. Kanemitsu MY, Loo LW, Simon S, Lau AF \& Eckhart W (1997). Tyrosine phosphorylation of connexin 43 by $\mathrm{v}$-Src is mediated by $\mathrm{SH} 2$ and $\mathrm{SH} 3$ domain interactions. J ournal of Biological Chemistry, 272: 22824-22831.

8. Loo LW, Berestecky J M, Kanemitsu MY \& Lau AF (1995). pp60src-mediated phosphorylation of connexin 43, a gap junction protein. J oumal of Biological Chemistry, 270: 12751-12761.

9. Wam-Cramer BJ , Lampe PD, Kurata WE, Kanemitsu MY, Loo LW, Eckhart W \& Lau AF (1996). Characterization of the mitogen-activated protein kinase phosphorylation sites on the connexin- 43 gap junction protein. J oumal of Biological Chemistry, 271: 3779-3786.

10. Kim DY, Kam Y, Koo SK \& J oe CO (1999).
Gating connexin 43 channels reconstituted in lipid vesicles by mitogen-activated protein kinase phosphorylation. J ournal of Biological Chemistry, 274: 5581-5587.

11. Hossain MZ, J agdale AB, Ao P, Kazlauskas A \& Boynton AL (1999). Disruption of gap junctional communication by the plateletderived growth factor is mediated via multiple signaling pathways. J ournal of Biological Chemistry, 274: 10489-10496.

12. Kanemitsu $M Y$, J iang $W \&$ Eckhart $W$ (1998). Cdc2-mediated phosphorylation of the gap junction protein, connexin43, during mitosis. Cell Growth and Differentiation, 9: 13-21.

13. Kwak BR, Saez J C, Wilders R, Chanson M, Fishman Gl, Hertzberg EL, Spray DC \& J ongsma HJ (1995). Effects of cGMP-dependent phosphorylation on rat and human connexin43 gap junction channels. Pflügers Archiv, European J ournal of Physiology, 430: 770-778.

14. Moreno AP, Fishman GI \& Spray DC (1992). Phosphorylation shifts unitary conductance and modifies voltage dependent kinetics of human connexin43 gap junction channels. Biophysical J ournal, 
62: 51-53.

15. Kwak BR \& J ongsma HJ (1996). Regulation of cardiac gap junction channel permeability and conductance by several phosphorylating conditions. Molecular and Cellular Biochemistry, 157: 93-99.

16. Kwak BR, van Veen TA, Analbers LJ \& J ongsma HJ (1995). TPA increases conductance but decreases permeability in neonatal rat cardiomyocyte gap junction channels. Experimental Cell Research, 220: 456-463.

17. Warn-Cramer BJ , Cottrell GT, Burt J M \& Lau AF (1998). Regulation of connexin-43 gap junctional intercellular communication by mitogen-activated protein kinase. J ournal of Biological Chemistry, 273: 91889196.

18. Hossain MZ, Ao P \& Boynton AL (1998). Platelet-derived growth factor-induced disruption of gap junctional communication and phosphorylation of connexin43 involves protein kinase $\mathrm{C}$ and mitogenactivated protein kinase. J ournal of Cellular Physiology, 176: 332-341.

19. Zhou L, Kasperek EM \& Nicholson BJ (1999). Dissection of the molecular basis of pp60(v-src) induced gating of connexin 43 gap junction channels. J ournal of Cell Biology, 144: 1033-1045.

20. Thomas D, Ritz MF, Malviya AN \& Gaillard S (1996). Intracellular acidification mediates the proliferative response of $\mathrm{PC} 12$ cells induced by potassium ferricyanide and involves MAP kinase activation. International J ournal of Cancer, 68: 547-552.

21. Yamaji Y, Tsuganezawa H, Moe OW \& Alpem RJ (1997). Intracellular acidosis activates c-Src. American J oumal of Physiology, 272: C886-C893.

22. Zanke BW, Lee C, Arab S \& Tannock IF (1998). Death of tumor cells after intracelIular acidification is dependent on stressactivated protein kinases (SAPK/J NK) pathway activation and cannot be inhibited by $\mathrm{BCl}-2$ expression or interleukin lbeta-converting enzyme inhibition. Cancer Research, 58: 2801-2808.

23. Ek J F, Delmar M, Perzova R \& Taffet SM (1994). Role of histidine 95 on $\mathrm{pH}$ gating of the cardiac gap junction protein connexin43. Circulation Research, 74: 10581064.

24. Turner CE \& Miller JT (1994). Primary sequence of paxillin contains putative $\mathrm{SH} 2$ and $\mathrm{SH} 3$ domain binding motifs and multiple LIM domains: identification of a vinculin and pp125Fak-binding region. J oumal of Cell Science, 107: 1583-1591.

25. Brown MC, Perrotta JA \& Turner CE (1998). Serine and threonine phosphorylation of the paxillin LIM domains regulates paxillin focal adhesion localization and cell adhesion to fibronectin. Molecular Biology of the Cell, 9: 1803-1816.

26. Lau AF, Kurata WE, Kanemitsu MY, Loo LW, Warn-Cramer BJ, Eckhart W \& Lampe PD (1996). Regulation of connexin43 function by activated tyrosine protein kinases. J oumal of Bioenergetics and Biomembranes, 28: 359-368.

27. Bruzzone $R$, White $T W \&$ Goodenough DA (1996). The cellular internet: on-line with connexins. Bioessays, 18: 709-718.

28. Moreno AP, Saez J C, Fishman GI \& Spray DC (1994). Human connexin43 gap junction channels. Regulation of unitary conductances by phosphorylation. Circulation Research, 74: 1050-1057.

29. Kwak BR \& J ongsma HJ (1996). Regulation of cardiac gap junction channel permeability and conductance by several phosphorylating conditions. Molecular and Cellular Biochemistry, 157: 93-99.

30. Kwak BR, van Veen TA, Analbers LJ \& J ongsma HJ (1995). TPA increases conductance but decreases permeability in neonatal rat cardiomyocyte gap junction channels. Experimental Cell Research, 220: 456-463.

31. Takens-Kwak BR \& J ongsma HJ (1992). Cardiac gap junctions: three distinct single channel conductances and their modulation by phosphorylating treatments. Pflügers Archiv, European J ournal of Physiology, 422: 198-200.

32. Liu S, Taffet SM, Stoner L, Delmar M, Vallano ML \& J alife J (1993). A structural basis for the unequal sensitivity of the major cardiac and liver gap junctions to intracellular acidification: the carboxyl tail length. Biophysical J ournal, 64: 14221433.

33. Morley GE, Ek-Vitorin J F, Taffet SM \& Delmar M (1997). Structure of connexin43 and its regulation by $\mathrm{pHi}$. J oumal of Cardiovascular Electrophysiology, 8: 939-951.

34. Homma N, Alvarado J L, Coombs W, Stergiopoulos K, Taffet SM, Lau AF \& Delmar M (1998). A particle-receptor model for the insulin-induced closure of connexin43 channels. Circulation Research, 83: 27-32.

35. Arellano RO, Rivera A \& Ramon F (1990). Protein phosphorylation and hydrogen ions modulate calcium-induced closure of gap junction channels. Biophysical J ournal, 57: 363-367.

36. De Mello WC (1984). Modulation of junctional permeability. Federation Proceedings, 43: 2692-2696.

37. Spray DC, White RL, de Carvalho AC, Harris AL \& Bennett MV (1984). Gating of gap junction channels. Biophysical J oumal, 45: 219-230.

38. Peracchia C, Wang X, Li L \& Peracchia LL (1996). Inhibition of calmodulin expression prevents low-pH-induced gap junction uncoupling in Xenopus oocytes. Pflügers Archiv, European J ournal of Physiology, 431: 379-387.

39. Bruzzone R, White TW \& Paul DL (1996). Connections with connexins: the molecular basis of direct intercellular signaling. European J ournal of Biochemistry, 238: 1-27. 